\title{
A novel missense in GLI3 possibly affecting one of the zinc finger domains may lead to postaxial synpolydactyly: case report
}

\author{
Qianqian Zou ${ }^{1 \dagger}$, Zhigang Tian ${ }^{2 \dagger}$, Jie Zheng ${ }^{1}$, Xiufang Zhi ${ }^{1}$, Xiaojie Du ${ }^{2}$, Jianbo Shu ${ }^{3 *}$ and Chunquan Cai ${ }^{4 *}$ (D
}

\begin{abstract}
Background: Polydactyly is one of the most common congenital hand/foot malformations in humans. Mutations in GL/3 have been reported to cause syndromic and non-syndromic forms of preaxial and postaxial polydactylies.
\end{abstract}

Case presentation: The patient was a 2-year-old boy who underwent surgery in our hospital. The right hand and left foot of the patient were labelled as postaxial polydactyly type B, and there was cutaneous webbing between the 3rd and 4th fingers of the left hand. We identified a novel c. 1622C > T variant in GLI3 leading to an isolated postaxial synpolydactyly.

Conclusions: The patient carries a novel autosomal dominant heterozygous missense mutation. This mutation c.1622C > T;p.(Thr541Met) in the GLI3 gene may affect the normal function of the zinc finger domain (ZFD) in a different way. However, it seems that more research is needed to determine the exact effects of this mutation.

Keywords: Synpolydactyly, GL/3 gene, Gene mutation

\section{Background}

Polydactyly is one of the most common hand-foot malformations in humans. Neonatal morbidity in the world is approximately $0.3 / 1000-3.6 / 1000$ and is approximately twice as high for males as for females [1]. This malformation can occur alone (non-syndromic type) and can also be combined with a variety of other symptoms (syndromic type) [2]. Genotype-phenotype correlation studies suggest that truncation mutations upstream of or within the zinc finger domain (ZFD) usually result in Greig cephalopolysyndactyly syndrome (GCPS). Protein truncation in the middle portion of the GLI3 protein is associated with Pallister-Hall syndrome (PHS). Mutations

\footnotetext{
* Correspondence: shjb1981@sina.com; cqcns6@126.com

${ }^{+}$Qianqian Zou and Zhigang Tian contributed equally to this work.

${ }^{3}$ Institute of Paediatrics, Tianjin Children's Hospital, No. 238 Longyan Road,

Beichen District, Tianjin, China

${ }^{4}$ Department of Neurosurgery, Tianjin Children's Hospital, No. 238 Longyan

Road, Beichen District, Tianjin, China

Full list of author information is available at the end of the article
}

that cause truncations in the C-terminal part of the GLI3 protein result in a variable phenotype of GCPS, postaxial polydactyly types A or B (PAP A/B) or preaxial polydactyly type IV (PPD IV) [3]. In this study, we report a boy with isolated postaxial synpolydactyly who carries a novel autosomal dominant heterozygous missense mutation near the ZFD of GLI3.

\section{Case presentation}

The patient was a 2-year-old boy who underwent surgery in the Department of Orthopaedics, Tianjin Paediatric Hospital. The right hand and left foot of the patient were labelled as PAP B, and there was cutaneous webbing between the 3rd and 4th fingers of the left hand. Phenotypic variability among the other 4 affected related individuals (great-grandmother, granduncle, grandfather, and father) was evident. Their hands were diagnosed as PAP B. The

(c) The Author(s). 2019 Open Access This article is distributed under the terms of the Creative Commons Attribution 4.0 International License (http://creativecommons.org/licenses/by/4.0/), which permits unrestricted use, distribution, and reproduction in any medium, provided you give appropriate credit to the original author(s) and the source, provide a link to the Creative Commons license, and indicate if changes were made. The Creative Commons Public Domain Dedication waiver (http://creativecommons.org/publicdomain/zero/1.0/) applies to the data made available in this article, unless otherwise stated. 
affected individuals did not have craniofacial dysmorphism (Fig. 1). A novel autosomal dominant heterozygous GLI3 variant, NC_000007.14(NM 000168.5):c.1622C > T; p.(Thr541Met), located in exon 11, was identified by Sanger sequencing of the patient's gDNA sample. His father and grandfather are heterozygous for the mutation, and his greatgrandmother has passed away (Fig. 2; Table 1). This variant was predicted to be most likely damaging, with a score of 1 (sensitivity: 0; specificity: 1) by Polyphen 2 [4]. Moreover, it is forecast to affect protein function, with a score of 0.00 according to SIFT [5]. The GLI3 variant is highly conserved in the evolution of various species, suggesting the functional importance of this protein (Fig. 3). The simplified model illustrating the mutation in GLI3 located near the second zinc finger structure in the ZFD was constructed with HOPE (Fig. 4).

\section{Discussion and conclusions}

Congenital limb abnormalities are the most common birth defects in new-borns. Polydactyly is one of the most common congenital limb malformations [2]. Human embryos start to form at the end of the fourth week of embryonic development. After approximately 4 weeks, the interactions of the genes and various factors play decisive roles in the formation of normal morphology, function and finger number [6]. During the formation of limbs, there are three interacting signalling centres that direct the formation of fingers. Abnormal genes in these signalling centres will result in congenital limb malformations. Recent studies have focused on genes and gene families related to limb development, such as SHH, ZRS and GLI3 [7]. Among them, GLI3 is currently known to be an important signalling molecule that regulates the anteroposterior axis direction [the direction of the first finger (toe) to the fifth finger (toe)] in human embryo development [8].

The GLI3 gene is located in the $7 \mathrm{p} 14.1$ region of the chromosome and consists of 14 exons. The mRNA of GLI3 is $8.5 \mathrm{~kb}$ in length and encodes a polypeptide chain consisting of 1580 amino acids
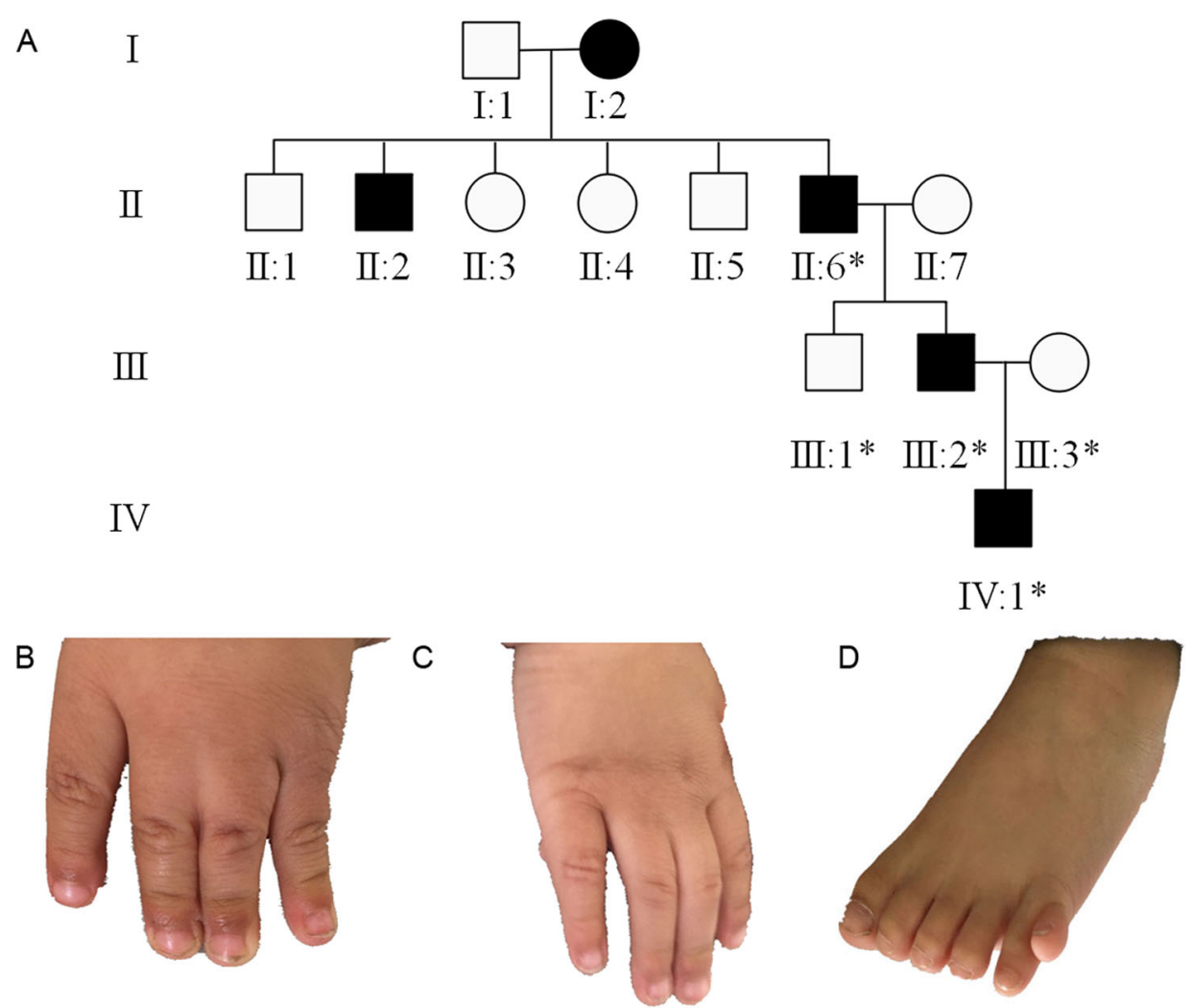

Fig. 1 The clinical phenotype. a. Family tree of the studied individuals (the individuals included in this study are specified by asterisks), Both hands of the proband's grandfather were classified as post-axial polydactyly type B (individual II:6). The father's left hand was classified as post-axial polydactyly type B (individual III:2). The patient's right hand was classified as post-axial polydactyly, and his left hand had cutaneous webbing between the 3rd and 4th fingers; his left foot had a well-formed digit on the fibular aspect (individual IV:1) (b, c and $\mathbf{d})$ 
II-6

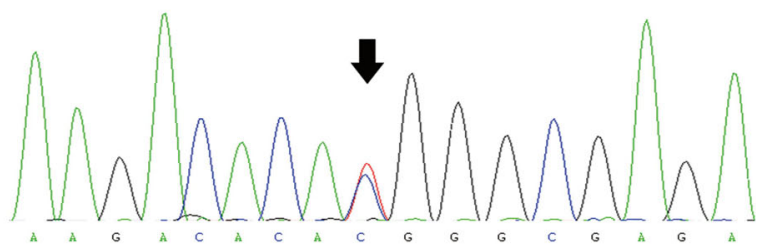

III-1

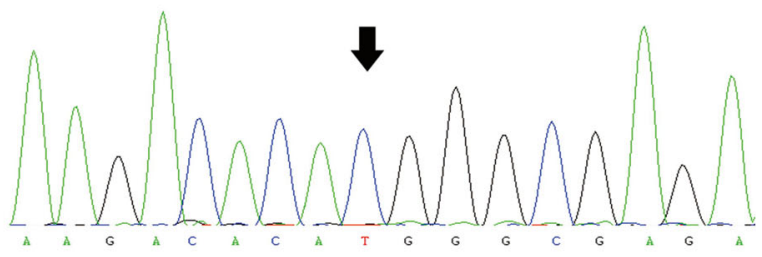

III-2

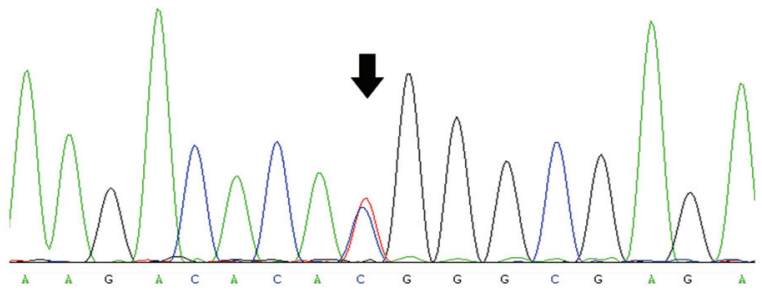

III-3

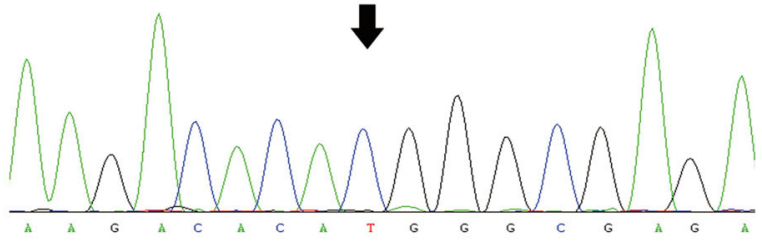

IV-1

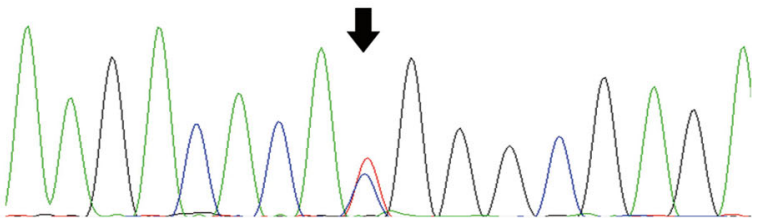

Fig. 2 Sequencing data of the GL/3 gene in the patient and his family. The arrows indicate the position of the C.1622C > T; p.(Thr541Met) substitution

Table 1 Clinical features of the affected individuals

\begin{tabular}{|c|c|c|c|c|}
\hline Affected individual & Sex & Age & Symptoms & Mutation \\
\hline Great-grandmother (individual l:2) & Female & Deceased & $\begin{array}{l}\text { Both hands were classified as post-axial } \\
\text { polydactyly type B }\end{array}$ & - \\
\hline Granduncle (individual II:2) & Male & 56 years & $\begin{array}{l}\text { Both hands were classified as post-axial } \\
\text { polydactyly type B }\end{array}$ & - \\
\hline Grandfather (individual II:6) & Male & 54 years & $\begin{array}{l}\text { Both hands were classified as post-axial } \\
\text { polydactyly type B }\end{array}$ & c.[1622C > T];p.[(Thr541Met)] \\
\hline Father (individual III:2) & Male & 34 years & $\begin{array}{l}\text { Left hand was classified as post-axial } \\
\text { polydactyly type B }\end{array}$ & c.[1622C > T];p.[(Thr541Met)] \\
\hline Patient (individual IV:1) & Male & 2 years & $\begin{array}{l}\text { Right hand was classified as post-axial } \\
\text { polydactyly, left hand had cutaneous } \\
\text { webbing between the } 3 \text { rd and } 4 \text { th } \\
\text { fingers, left foot had a well-formed } \\
\text { digit on the fibular aspect. }\end{array}$ & c.[1622C > T];p.[(Thr541Met)] \\
\hline
\end{tabular}




\begin{tabular}{|c|c|c|}
\hline & Thr541Met & \\
\hline Human & VCRV̆LICSREQRPERAQYMLVVHMRRHTGERPHKCTEEGC & 553 \\
\hline Chimpanzee & VCRV̆LLCSREQKPEKAQYMLVVHMRRHTGEKPHKCTEEGC & 553 \\
\hline Dog & VCRKMLCSREQREFRAQYMLVVHMRRHTGEKRHKCTEEGC & 552 \\
\hline House & VCRV̈LICSREQKPEKACYMLVVHMRRHTGEKPHKCTEEGC & 553 \\
\hline Chicken & VCRЙLLCSREQKREKAQYMLVVHMRRHTGEKPHKCTEEGC & 554 \\
\hline Zebrafish & VCRЙEECSREQKEEKAQYMLVVHMRRHTGEKRHKCTEEGC & 559 \\
\hline Consensus & $\overline{\text { vcrw }} \overline{\text { csreqkpfkaqymlvvhmrrhtgekphkctfegc }}$ & \\
\hline
\end{tabular}

[9]. The protein can be divided into 3 parts that are associated with different genotype-phenotype correlations: the ZFD, the cyclic AMP-binding proteinbinding domain (CBPD), and the transactivation domains 1 and 2 (TA1 and 2). The ZFD contains five highly conserved tandem zinc finger structures with specific DNA sequence affinity (2 cysteine and 2 histidine, $\mathrm{C} 2 \mathrm{H} 2$ ). It is a central zinc finger transcription factor in the early development of vertebrate limbs [10]. The mutation is near one of the $\mathrm{C} 2 \mathrm{H} 2 \mathrm{~s}$, which contains the 513-540 region in GLI3. In some cases, mutations of the ZFD usually result in a reduced expression of GLI3, which leads to an expanded expression of the active forms of GLI3 (GLI3A) compared to the repressor forms of GLI3 (GLI3R). These point mutations throughout the
GLI3 gene are well known for causing the GCPS phenotype. Instead, the boy we report carries a novel autosomal dominant heterozygous missense mutation NC_000007.14(NM_000168.5):c.1622C > T; p.(Thr541Met) near the ZFD of GLI3 associated with isolated postaxial synpolydactyly. Some articles have suggested that the perturbation of the balance of GLI3R and GLI3A is connected to postaxial polydactyly. A mildly abnormal ratio of GLI3R to GLI3A can result in isolated postaxial polydactyly. Therefore, the mutation in our case may affect the normal function of the ZFD in a different manner. Further experiments will be necessary to confirm how this mutation works. We believe that there is practical significance for further studies of synpolydactyly.

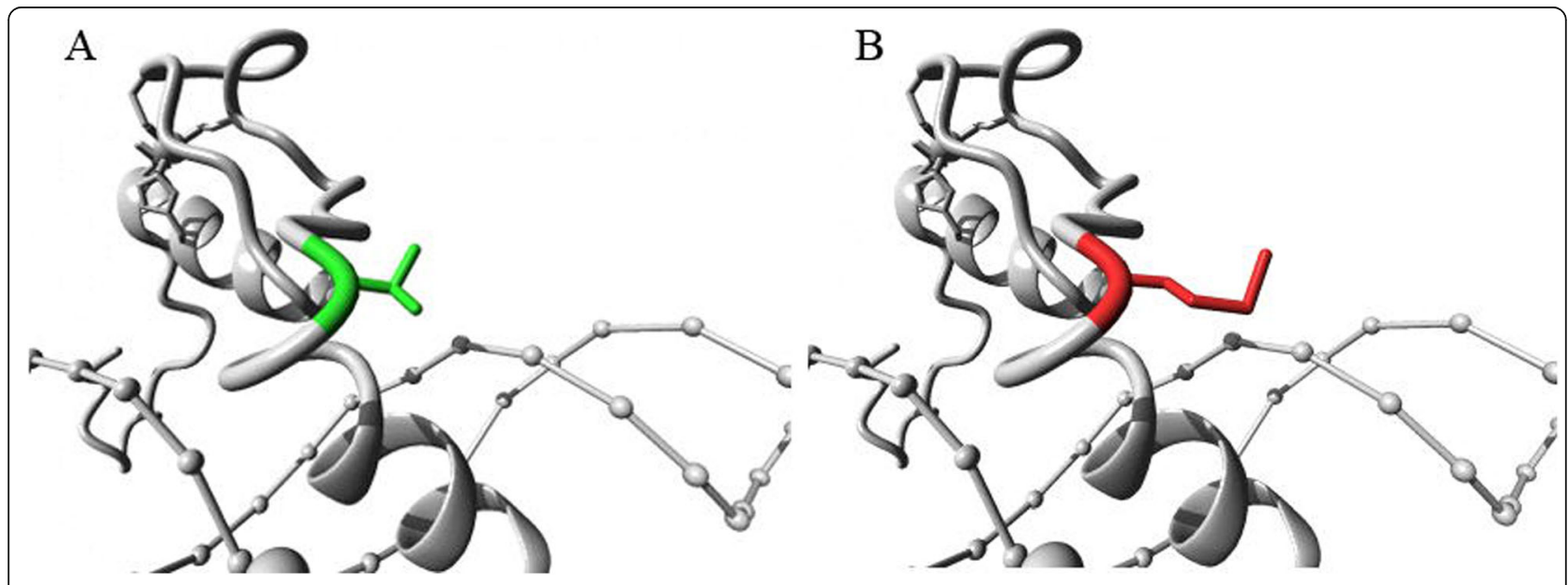

Fig. 4 Structural modelling of the predicted wild type (a) and mutant p. Thr541Met (b) proteins. The mutation is near the second zinc finger 


\section{Abbreviations}

$\mathrm{C} 2 \mathrm{H} 2$ : 2 cysteine and 2 histidine; CBPD: Cyclic AMP-binding protein-binding domain; GCPS: Greig cephalopolysyndactyly syndrome; GLI3A: The active forms of GLI3; GLI3R: The repressor forms of GLI3; PAP A/B: Postaxial polydactyly types A or B; PHS: Pallister-Hall syndrome; PPD IV: Preaxial polydactyly type IV; TA1 and 2: Transactivation domain 1 and 2; ZFD: Zinc finger domain

\section{Acknowledgements}

Not applicable.

\section{Authors' contributions}

QZ contributed to the conception and design of the study, literature search, experimental studies, and drafting of the manuscript; ZT contributed to the clinical data acquisition and manuscript editing and review; JZ contributed to the clinical data acquisition and manuscript editing and review; XZ contributed to the Sanger sequencing analysis and manuscript editing and review; XD contributed to the clinical data acquisition and manuscript editing; JS contributed to the conception and design of the study and manuscript editing and review; CC contributed to the conception and design of the study, literature search, experimental studies and manuscript editing and review. All authors read and approved the final manuscript.

\section{Funding}

This study was funded by the Key Project of Tianjin Health and Family Planning Commission Natural Science Foundation [grant number 2015KR12]; the Key Project of Tianjin Health Care Professionals [grant number 16KG166]; the National Natural Science Foundation of China [grant number 81771589]; the Programme of Tianjin Science and Technology Plan [grant number 18ZXDBSY00170]. No funders participated in the design of the study; the collection, analysis, and interpretation of data; or the writing of the manuscript.

\section{Availability of data and materials}

The datasets used and analysed during the current study are available from the corresponding author on reasonable request.

\section{Ethics approval and consent to participate}

The present study protocol was approved by the Ethics Committee of Tianjin Children's Hospital (reference number: 20180519). Written informed consent to participate was obtained from the relatives of the patient.

\section{Consent for publication}

Written informed consent for publication of the relative's clinical details and clinical images was obtained from the relatives of the patient. Written informed consent for publication of the male patient's clinical details and clinical images was obtained from the parent of the patient. A copy of the consent form is available for review by the Editor of this journal.

\section{Competing interests}

The authors declare that they have no competing interests.

\section{Author details}

${ }^{1}$ Graduate College of Tianjin Medical University, Tianjin, China. ${ }^{2}$ Department of Orthopaedics, Tianjin Children's Hospital, Tianjin, China. ${ }^{3}$ Institute of Paediatrics, Tianjin Children's Hospital, No. 238 Longyan Road, Beichen District, Tianjin, China. ${ }^{4}$ Department of Neurosurgery, Tianjin Children's Hospital, No. 238 Longyan Road, Beichen District, Tianjin, China.

Received: 26 April 2019 Accepted: 6 September 2019

Published online: 09 November 2019

\section{References}

1. Castilla E, Paz J, Mutchinick O, Munoz E, Giorgiutti E, Gelman Z. Polydactyly: a genetic study in South America. Am J Hum Genet. 1973;25(4):405-12.

2. Biesecker LG. Polydactyly: how many disorders and how many genes? Am J Med Genet. 2002;112(3):279-83.

3. Al-Qattan MM, Shamseldin HE, Salih MA, Alkuraya FS. GLI3-related polydactyly: a review. Clin Genet. 2017;92(5):457-66.
4. Adzhubei IA, Schmidt S, Peshkin L, Ramensky VE, Gerasimova A, Bork P, Kondrashov AS, et al. A method and server for predicting damaging missense mutations. Nat Methods. 2010;7(4):248-9.

5. Sim NL, Kumar P, Hu J, Henikoff S, Schneider G, Ng PC. SIFT web server: predicting effects of amino acid substitutions on proteins. Nucleic Acids Res. 2012;40(Web Server issue:W452-7.

6. Kuijper S, Feitsma H, Sheth R, Korving J, Reijnen M, Meijlink F. Function and regulation of Alx4 in limb development: complex genetic interactions with Gli3 and Shh. Dev Biol. 2005;285(2):533-44.

7. Biesecker LG. Polydactyly: how many disorders and how many genes? 2010 update. Dev Dyn. 2011:240(5):931-42.

8. Hill P, Gotz K, Ruther U. A SHH-independent regulation of Gli3 is a significant determinant of anteroposterior patterning of the limb bud. Dev Biol. 2009;328(2):506-16.

9. Demurger F, Ichkou A, Mougou-Zerelli S, Le Merrer M, Goudefroye G, Delezoide AL, Quelin C, Manouvrier S, Baujat G, Fradin M, et al. New insights into genotype-phenotype correlation for GLI3 mutations. Eur J Hum Genet. 2015;23(1):92-102

10. Kang S, Rosenberg M, Ko VD, Biesecker LG. Gene structure and allelic expression assay of the human GLI3 gene. Hum Genet. 1997;101(2):154-7.

\section{Publisher's Note}

Springer Nature remains neutral with regard to jurisdictional claims in published maps and institutional affiliations.
Ready to submit your research? Choose BMC and benefit from:

- fast, convenient online submission

- thorough peer review by experienced researchers in your field

- rapid publication on acceptance

- support for research data, including large and complex data types

- gold Open Access which fosters wider collaboration and increased citations

- maximum visibility for your research: over $100 \mathrm{M}$ website views per year

At $\mathrm{BMC}$, research is always in progress.

Learn more biomedcentral.com/submissions 